\title{
PREFACE TO THE PAPERBACK EDITION
}

The hardback edition of Grave New World was published shortly before Emmanuel Macron's victory in the 2017 French presidential election. For some, Macron's success suggested that globalization was still very much on track. Even if Donald Trump was threatening to build a wall on the US's southern border and the UK was intent on leaving the European Union, Macron was a man who promised to uphold the institutions of globalization. Most obviously, he was keen to safeguard and indeed enhance the four freedoms - of goods, services, capital and people - that, for many, are the bedrock of European integration.

Elsewhere in Europe, however, events were less encouraging: Poland and Hungary continued their lurch to the right, embracing values that appeared to be not fully consistent with those emanating from Brussels; the Catalonian separatist movement refused to go away; the far right gained power in Austria; and Angela Merkel discovered that her prorefugee policies had provoked an anti-refugee backlash that in turn had triggered rising support for Alternative für Deutschland.

Meanwhile, even as the US appeared to be beating a retreat from its hitherto mostly enthusiastic embrace of globalization, China's ambitions 
were steadily advancing. President Xi was happy to be regarded as globalization's new standard-bearer, even if his version of globalization - a 'Belt and Road' that might eventually serve to connect China with the rest of Asia, Europe and Africa - could hardly be described as stemming from the Western liberal democratic tradition.

For many in Asia, globalization continues to advance unabated, helped along by China's immense gravitational pull. Yet with Washington threatening to impose trade sanctions on China and with uncertainties lingering over the future of the Korean peninsula, it's not clear whether cordial relations between the world's two twenty-first-century superpowers will be easily maintained. If they are not, we're likely to find globalization splintering further as rival regional alliances develop.

Underneath all this, the West still faces a fundamental political problem. With lower growth rates than before and with a much greater focus on inequality - of income, wealth and opportunity - the temptation is to use globalization as a scapegoat. Rather than thinking about failures closer to home - on tax, education and social mobility - too many politicians from across the political spectrum have opted to blame the rest of the world, sometimes aiming at particular countries (the fault lies with China or Mexico, say) and sometimes aiming at the 'system' as a whole (there's an international capitalist conspiracy). It is, of course, a well-trodden path. History, however, suggests that such an approach is only likely to end in tears.

London, January 2018 